\title{
TEACHING CHARACTER EDUCATION TO PRIMARY SCHOOL STUDENTS THROUGH JAVANESE ETHNOLINGUISTICS
}

\author{
Oktaviani Adhi Suciptaningsih ${ }^{\mathrm{a}}$, Suwarno Widodo ${ }^{\mathrm{b}}$, Titik Haryati ${ }^{\mathrm{c}}$ \\ ${ }^{\text {a }}$ Faculty of Economics, Universitas PGRI Semarang, Semarang, Indonesia \\ ${ }^{\mathrm{b}}$ Faculty of Social Sciences and Sport Science, Universitas PGRI Semarang, Semarang, Indonesia \\ ${ }^{\mathrm{c}}$ Faculty of Social Sciences and Sport Science, Universitas PGRI Semarang, Semarang, Indonesia
}

Corresponding e-mail: osuciptaningsih@yahoo.co.id

\begin{abstract}
Globalization as the most powerful phenomenon of the present time is widely contested for its positive and negative outcomes. To Indonesian context, particularly to the Javanese, it brings more negative impacts than the advantages causing the decrease of primary school students' character as seen from their disobedient to be the observance of their own indigenous culture and ethics. The purpose of this research is to find out the impact of Javanese ethno-linguistics intervention to the character of primary school students. This research used qualitative method. There were 60 lower primary school students (class IV) taken as the subject of the study. They were from four Elementary schools at Central Java. The research had been conducted for three months. The data were collected through observation, interview and documentation. The data were triangulated and analyzed by using Miles and Huberman techniques. The results showed that after giving ethno-linguistic treatment for three months teaching the students through Javanese song, Geguritan (Javanese poems), macapat (Javanese hymne) and geguritan competitions, and various Javanese literacy activities, the students show positive changes of their characters. They show more appreciation to others; they love their indigenous heritage, have good manners, use kromo alus (the most polite style), and become more obedient to their parents. These results are so much different from their characters before the treatment. It can be concluded that the ethno-linguistic approach can improve students' characters.
\end{abstract}

Keywords: character education, primary school students, javanese ethno-linguistics

\section{INTRODUCTION}

Globalization is rightly described as a phenomenon characterized by the separation of time and space and their stretching beyond any boundaries, whereby the immediate surroundings are shaped by the distant happenings and vice versa [1][2][3]. In globalization age, there is an increasing of interconnection and interdependence among people across the globe through various forms of activities, such as trading, traveling, investment, popular culture and other form of interactions that lead to the narrowness of the geographic, economic and cultural boundaries of a country [4][5][6][7]. Globalization is also referred to 'Westernisation", which can be noticed by the prevalence of Western norms, clothing (jeans), drinking eating habits (fast food and Coke) etc. across the globe.

To Indonesian scientists, globalization is interpreted as internationalization of historical process [8][9][10], political process [11][12][13] social process [14], Natural process [15] that bring the world community to a new order of life.

There are several forms of globalization, namely globalization of communications and information technologies, finance and trade (economic globalization), international movements of people, political globalization linguistic, cultural and ideological convergence, and globalization of education in the new millennium [16][17][18]. 
Globalization in Indonesian context, particularly in the domain of Javanese culture, has brought more negative impacts than the advantages. It has deteriorated Javanese indigenousity. It has caused the decrease of primary school students' character as seen from their disobedient to be the observance of Javanese culture and ethics.

After observing the students for three years at several elementary schools in Central Java Province, the researchers found the students have neglected the Javanese registers or ungguh-ungguh (etiquette) when communicating with senior citizen or talking to the elders. They use ngkoko or informal speech which is used only between friends and relatives to communicate with the person who are older than them. They should speak in krama or in a polite register. Their behaviors are out of Javanese ethic as they do not shake hand with the teachers or parents when meeting them; they don't practice bowing when leaving and do not say excuse me or nuwun sewu or amit when passing in front of other people; they no longer say "kulo nuwun" or say greeting when meeting people; they even only knock the door when coming home or visiting other houses without saying excuse me or asking anybody home. They do not conduct themselves in a formal or informal situation. Those bad behaviors do not belong to the Javanese and they should not be practiced by lower primary school students since they are very young and the future generation.

Education should be able to instill good character into the pupils. To educate means not only to drill psychomotor skill and the conceptual skill. It does not deal with scientific intelligent and mind, but it is also related to the spiritual, attitude, cultural, and moral intelligent. At the moment cognitive or conceptual skill in the primary education is more dominant compared to affective or psychomotor domain.

Character education program consists of three attributes such as moral knowledge, moral feeling, and moral behaviour [19].

Character education is a conscious attempt to help students acquire objectively worthwhile virtues. Students do not decide for themselves what is right and wrong; rather, the school (or other organizations) stands for virtues like respect and responsibility and promotes them explicitly at every turn. It is conscious effort to form the habit of thinking and behaving well of an individual in order to adapt to his/her environment [20][21][22][23].

It should be acknowledged that despite the globalization processes in all socio-economic, education, and cultural spheres, the people need to

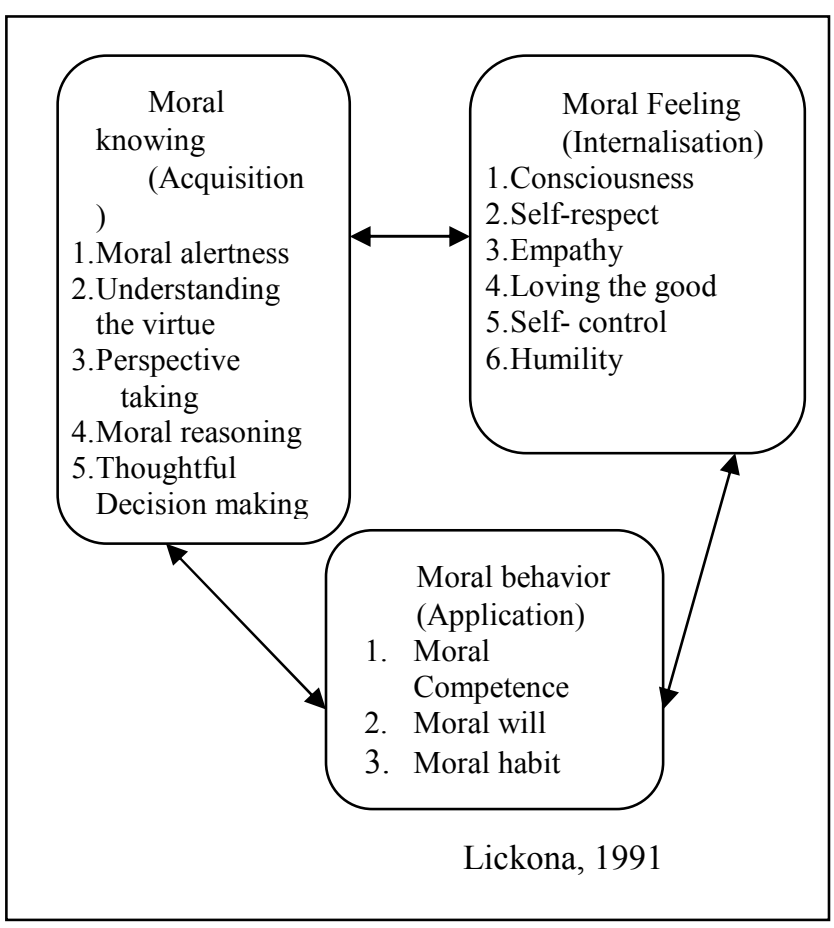

assert their indigenous and national character. Globalization in Indonesia needs to be evaluated as it may cause bad moral behavior of primary schools students. The indication was recorded by the researchers that many of the lower primary school students cannot speak their own mother tongue[24], they cannot write Javanese script[25][26], they do not know Javanese literature (such as geguritan, Chanting, kakawin); they cannot sing Javanese song Inembang Jawa (for example macapat songs, like Gambuh, Pocong, Asmaradana, Pangkur, Sinom and others). Primary school students today prefer foreign music (eg jazz, ballad, rock), reading novels (like Harry Potter novels), watching animated films (eg Spiderman, Batman, Transformers). The rapid flow of globalization raises students' indifference to everything that happens in their environment, including their own culture. They regarded the Javanese culture as the belonging of ancient people or out of date. Globalization should not diminish a sense of Javanese identity but reinforce it. The students may facilitate the expansion of national identities and also provide cultural resources which can be domesticated, enfolded within popular and everyday national cultures.

School has an important role in the process of character education for students. Pupils spend most of their time at school, so what they get at school will affect the formation of their character. Schools as institutions that perform services to societies with 
social, moral and academic emphasis are responsible for integrating character education in all disciplines of learning materials or in every aspect of the curriculum [27]. Moreover elementary school (SD) is the most basic level of formal education in Indonesia.

SD has a strategic role in imposing character values into the students. Early character values implanted through habituation at school can shape the personality of the student. In accordance with the stages of child development, the teaching of national values at lower primary education is easier than in middle age children [28]. It is assumed that if the children have strong Javanese background, globalization will not damage local ingeniousity like in Japan. Globalization in Japan has little influence over national identity because Japanese national identity has been very strong for years since the success in writing an identity from the seventh century onwards, especially from 1868 . Moreover, globalization in Japan works for co-development rather than fragmentation of Japanese ingeniousity [29].

Character education at lower primary education in Central Java Province can be done through ethnolinguistic approach. Ethno-linguistics is the study of the process of cultural formation and its interrelationship with language [30][31]. In this case, of course, Javanese culture and language, because the province of Central Java Javanese culture. Javanese culture is a great culture. The Javanese are known for their subtle, full of etiquette and courtesy. The children should use "humble" words concerning themselves, but honorific words concerning anyone of greater age of higher social status. The humilific words are called "krama andhap", while the honorifics are called "karma inggil". Children typically use the "ngoko" style, but in talking to the parents they must be competent with both "krama inggil" and "krama andhap". Therefore teaching character education to primary schools students through Javanese Ethno-linguistics is very important.

\section{METHODS}

This research used qualitative method. Total subjects were 60 students comprising of fourth grade students of SD N 1 Addrejo, fourth grade students of SD N 2 Sukorejo (Kendal District), fourth grade students of SD N 2 Sekaran, and fourth grade students of SD N 2 Ngijo (Semarang City). The data were collected through observation, interview, and documentation.
The data were triangulated and analyzed by using Miles and Huberman techniques.

\subsection{Character Education at Elementary School (SD) And Javanese Ethno- Linguistic}

The word character is derived from the Latin meaning "sculpted". Literally, character is a mental/ moral quality, moral strength, name or reputation. In the Dictionary of psychology, character is defined as the personality in terms of ethical or moral starting point, such as the honesty of a person; usually it has a connection with the properties of a relatively fixed. Character education then means teaching the children in a manner that will help them develop variously as moral, civic, good, mannered, behaved, non-bullying, healthy, critical, successful, traditional, compliant or socially acceptable beings [32].

Within the framework of the definition above, it can be inferred that individuals with good character are individuals who can make decisions and are prepared to account for any consequences of decisions made. Thus, character formation in Indonesia is one of the goals of national education. Article I of the SISDIKNAS Law of 2003 states that among the goals of national education is to develop the potential of students to have intelligence, personality and noble character.

Article 1 of SISDIKNAS Year 2003 above was intended to prepare smart Indonesian human resources with good personality or character. As mentioned by Martin Luther King, the importance of education in our communities, if not for the goal of intelligence than for the goal of social living. "The function of education is to teach one to think intensively and to think critically". Intelligence alone is not enough. According to him, intelligence plus character that is the goal of true education. The complete education gives one not only power of concentration, but worthy objectives upon which to concentrate. The broad education will, therefore, transmit to one not only the accumulated knowledge of the race but also the accumulated experience of social living. Character in the form of personality qualities is not a finished product, but through a seriously, consistently and creatively taught education process that started from the smallest unit in the family, then the community and educational institutions in general.

Character education has the same essence and meaning with ethic education and behavior education. The goal is to shape the personality of a child to become a good human being, a good citizen and citizen [33]. Character education is everything 
the teacher does, which is able to influence the character of the learner. Teachers help shaping the character of learners. Teaching by example includes giving examples to the students how to behave, to speak politely or to deliver the lesson material in a good manner, to tolerate differences, and others related activities [34].

Teaching character education to the elementary school students can be done through ethno-linguistic approach. Etno-lingustic consists of the word ethnology and linguistics, which means the study of an ethnic culture and its language. Ethno-linguistics can be grouped into two categories; (1) linguistic studies that contribute to ethnologists and (2) ethnological studies that contribute to linguistics. The study of the language problem of a society is a cultural phenomenon, which can be used as an understanding of a culture [35].

There have been so many previous researches done in the field of character education [36][37][38], but all of them are done in partial not in a holistic approach. So the results cannot yet reflect the existence of Javanese cultural in the educational setting.

Teaching character education to the elementary school students was conducted through Javanese ethno-linguistics at SD $\mathrm{N} 1$ Addrejo, SD $\mathrm{N} 2$ Sukorejo, SD N 2 Sekaran, and SD N 2 Ngijo. Were conducted by introducing Javanese culture to the students. Here is character education through Javanese ethno-linguistics on all four elementary schools:

- Integration of Javanese cultural in the teaching and learning process. This is done through the course of Javanese language. Here are the detail applications.

\section{1. "Krama" Javanese language variety}

The Javanese language as a product of Javanese society reflects the Javanese culture. The nature and behavior of the Javanese community can be seen through the language use or language varieties used in the community."Krama" is the most polite variety of Javanese used for communication from the younger to the elder of from the speaker of common people to the king or royal family.

At elementary school, this variety was taught for writing, reading, listening, and speaking purposes. Writing aims to develop the ability to express opinions, ideas, messages and feelings in writing. Reading is given to develop the ability to understand the content of the reading, in which the meaning of the reading is determined by the situation and context in the reading. Listening is basically the same as reading activities, but in listening to emphasis is given more on understanding spoken text. Speaking is done to develop the ability to express opinions, ideas, messages and feelings in "Krama" variety. The program was completed with Javanese literary appreciation.

Javanese language has its own function, including [39]:

a. Javanese language functions as cultural heritage. It means besides as a means of communication it also serves as a means of embodiment of cultural attitudes that are loaded with noble values,

b. Javanese language function as indicator of particular manners, knowing how to use good customs and having a sense of responsibility for the betterment of life together, and

c. In order to achieve the modesty, Javanese language can be personal embellishment. Then the conditions that must take into consideration is the attitude to be wise in understanding the feelings of others in the community, respect friends and opponents, and keep promise, polite, and do not hurt other people.

Javanese language has three vaieties: "ngoko", "madya", and "krama". "ngoko" is a the lowest variety which signified by "ngoko vocabularies/ngoko lexicon. Among the affixes in "ngoko" are "di-", "-e", and "-ake". "Ngoko" can be divided into two categories: "ngoko lugu" and "ngoko alus". "Ngoko lugu" is a form of Javanese varieties that all of its vocabulary is "ngoko" or neutral ("ngoko" and neutral)."krama" is diveded into "krama inggil", or "krama andhap '. The affix used is affix "di-," -e ", and" -ake ". "Ngoko alus" is a form of javanese variety which consists of "lexicon ngoko", neutral and "lexicon krama inggil", "krama andhap", and "krama". The affixes used in the most polite "ngoko halus " are "in-", "-e", and "-ne"

The affixes used in "Krama" are "dipun-", "ipun", and "-aken". The variety of "manners" has two variant forms: "krama lugu" and "krama alus". The "Krama lugu" is a kind of "krama" variety of low-grade content. However, "ngoko alus" still shows the level of nobility. Ordinary people usually use "krama madyal medium "krama". It uses affix "ngoko" "di-," -e ", and" -ake "rather than affix" dipun- "," though ", and" -aken ". In addition to the affix "ngoko", "midday klitik" "mang-" also often appear in this variety. While "krama alus" is a Javanese varieties that has vocabulary from "lexicon krama" and can be added with "lexicon krama inggil" or "krama andhap". But the core "lexicon" in this variety is the "karma lexicon". Medium "lexicon" and "lexicon ngoko" never appear in this 
variety. "Lexicon krama inggil" and "andhap" are used as a tribute to the other person. In this variety the affixes used are "dipun-", "though", and "-aken" which tend to appear more frequently than the affixes "di-," -e ", and" ake "affixes.

The Javanese language ethics does not only regulate the use of "ngoko" or "krama" variety, but also includes the attitude and manners shown by someone while speaking. The ethics contain values of character and courtesy when interacting with others. Javanese learning can be seen as one of the best tools to develop the noble character and personality of the students [40].

The research results show that the students of Grade VI SD N 1 Tambahrejo are more fluent in Javanese language, some are using "ngoko alus" while others are using "krama" although not "krama inggil". Most of the students were able to do code switching when using Javanese "ngoko" or when to use "krama". For example when talking to peers and juniors then they use "ngoko alus", when talking to seniors, and fathers, mothers, teachers, and parents they will change into "kromo". Student of SD N 1 Tambahrejo are more skilled at using Javanese either "ngoko" or "krama" than the other primary school students because they are accustomed to using the two languages as a medium of instruction in everyday life.

Although both elementary schools are located in one district of Kendal, most students of SD N 2 Sukorejo use a mixed language of Javanese language and Bahasa Indonesian. They live in the capital of the district where the community is plural. Many Sukorejo residents work outside the region and many residents are from outside Sukorejo, such as the Chinese, the Borneo, the Jakarta people, the Sundanese and others who settle as migrants, resulting in cultural interactions among the people, including the use of Bahasa Indonesia as a means of communication. They speak Javanese language with different dialect, accent and vocabulary. They sometime mix the Sundanese, Indonesian, Chinese, and other local vernaculars. This of course affects student in using expressions/ vocabulary and javanese language when communicating with others. Only few students are fluent in Javanese "ngoko alus" or "krama". Some of them can only speak "ngoko lugu".

Similarly, the mastery of Javanese language by the students at the grade VI of SD N 2 Sekaran and SD N 2 Ngijo which located in the city of Semarang were quite different. Since the SD N 2 Sekaran is located near the campus of Universitas Negeri Semarang (UNNES), its students are a bit more multilingual as they were influenced by university students who come from many parts of Indonesia. As the results the students' mastery of the Javanese language both "ngoko alus" and "krama" became low. It was replaced by slang of different local dialects. At SD N 2 Ngijo the students show different ability of speaking javanese language. Although this primary school is not so far from UNNES, the community still use javanese in the village, so the students can speak Javanese "ngoko alus" and "krama", although the percentage is not so much.

\section{2. "Javanese script"}

"Javanese script" is derived from "Brahmi script" used for the writing texts of Javanese, Madurese, Sundanese, Balinese and Sasak vernacular. The "Brahmi Script" is taken from the Sanskrit ${ }^{[41]}$. The Javanese "script" has 20 core characters complemented by the use of "sandhangan" and "spouse" in forming a word or sentence.

The example of Javanese scripts are given below;

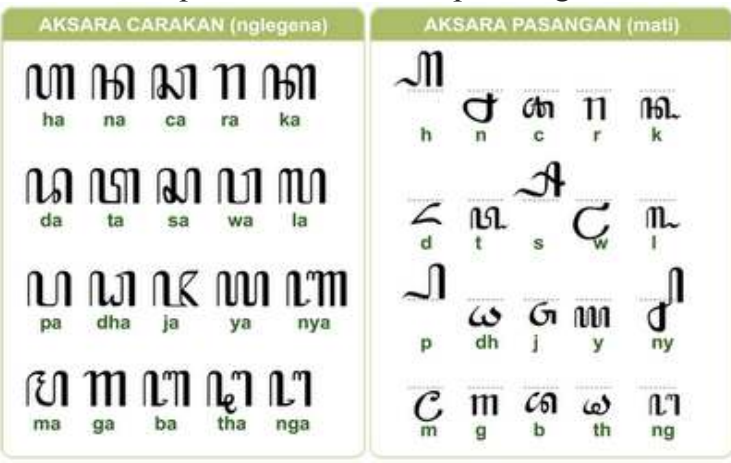

Pelengkap huruf

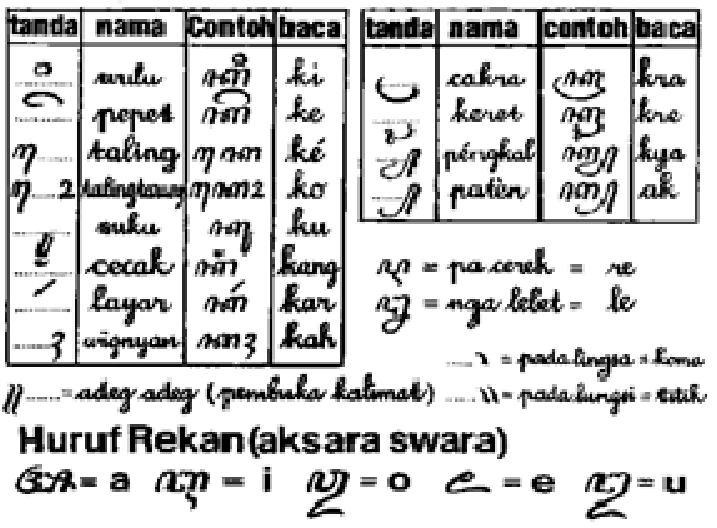

Students are taught to write words using the Javanese script, starting from writing their own name, to stringing words in a sentence using Javanese script. Here's an example: 


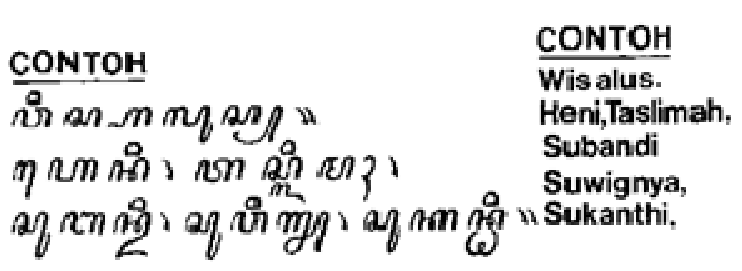

Students' skills in writing sentences using Java script is very varied. Some of them are able to write correctly while others are difficulties and some of them even cannot write any sentences. This is because students find it difficult to memorize various forms of "Java script" This is because Java script is always followed by "pasangan" and "sandhangan" [42].

\section{Macapat Song}

Macapat song contains deep meanings that are often used as expressions to express 'in' or out of paragraph. Macapat song is often used as a depiction of life that also contains advice or good advice to live. Macapat song consists of eleven types or titles. Each has different characteristics and values. Among eleven (11) Macapat Songs are Maskumambang, Kinanthi, Kinanthi, Sinom, Asmarandana, Gambuh, Dandanggula, Durma, Pangkur, Megatruh, Pocung. Each has its own character that sets it apart from other songs. These characteristics are used as standard rules, such as in the number of "guru gatra" (number of lines), "guru wilangan" (number of syllables per line), and "guru track" (final vowel in each line of sentence). Here are "guru gatra", "guru wilangan" and "guru song";

Table 1. Guru Gatra, Guru Wilangan, Guru Lagu Tembang Macapat

\begin{tabular}{|c|c|c|c|}
\hline \multicolumn{4}{|c|}{ Tembang Macapat } \\
\hline $\begin{array}{l}\text { Tembang } \\
\text { Macapat }\end{array}$ & $\begin{array}{l}\text { Guru } \\
\text { gatra }\end{array}$ & Guru wilangan & Guru lagu \\
\hline Mijil & 6 & $10,6,10,10,6,6$ & $\mathrm{i}, \mathrm{o}, \mathrm{e}, \mathrm{i}, \mathrm{i}, \mathrm{u}$ \\
\hline Sinom & 9 & $\begin{array}{l}8,8,8,8,7,8,7 \\
8,12\end{array}$ & $\begin{array}{l}\text { a, i, a, i, i, u } \\
\text { a ,i, a }\end{array}$ \\
\hline Dhandhanggula & 10 & $\begin{array}{l}10,10,8,7,9,7 \\
6,8,12,7\end{array}$ & $\begin{array}{l}\text { i, a, e, u, i, a, } \\
\text { u , a ,i, a }\end{array}$ \\
\hline Kinanthi & 6 & $8,8,8,8,8,8,8$ & $\mathrm{u}, \mathrm{i}, \mathrm{a}, \mathrm{i}, \mathrm{a}, \mathrm{i}$ \\
\hline Asmarandana & 7 & $8,8,8,8,7,8,8$ & $\begin{array}{l}\mathrm{a}, \mathrm{i}, \mathrm{e}, \mathrm{a}, \mathrm{a}, \\
\mathrm{u}, \mathrm{a}\end{array}$ \\
\hline Durma & 7 & $12,7,6,7,8,5,7$ & a, i, a, a, i, a, \\
\hline Pangkur & 7 & $\begin{array}{l}8,11,8,7,12,8 \\
8,\end{array}$ & $\begin{array}{l}\mathrm{a}, \mathrm{i}, \mathrm{u}, \mathrm{a}, \mathrm{u}, \\
\mathrm{a}, \mathrm{i}\end{array}$ \\
\hline Maskumambang & 4 & $12,6,8,8$ & $i, a, i, a, a$ \\
\hline
\end{tabular}

\begin{tabular}{|l|l|l|l|}
\hline Pucung & 4 & $12,6,8,12$ & u, a, i, a \\
\hline Gambuh & 5 & $7,10,12,8,8$ & u, u, i, u, o \\
\hline Megatruh & 4 & $12,8,8,8$, & u, i, u, i, o \\
\hline
\end{tabular}

Besides having provisions in terms of "guru gatra", "guru wilangan" and "guru song". Macapat songs also have distinct characteristic. The character of this song is used to adjust the lyrics of the song that is made so that it can be in accordance with the song characters. In addition to the character, the 11th song is actually a series of stories that made in a coherent manner; it becomes a form of picture of the journey of human life, which is started from the mother's womb, until humans return to God Almighty or died. Here is an example of Macapat song:

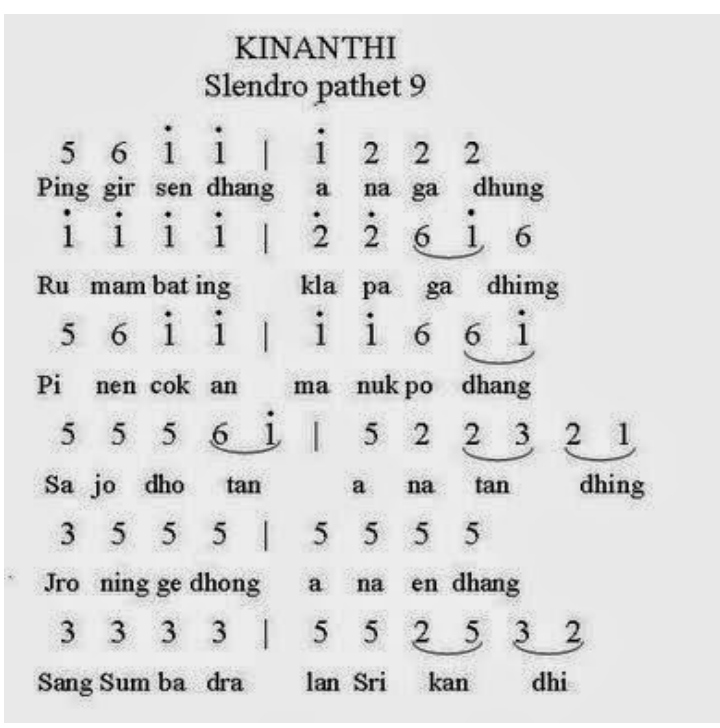

Here is the content of Kinanthi song. First the word Kinanthi is originated from the word 'kanthi' means "to hold" or "guide". Kinanthi is a story that illustrates the life of a child who still needs the guidance in order to live in this world. The guide that a child needs is not only physical assistance as a toddler, but also guidance in searching the meaning of various norms and customs that use in the community. Thus, they can learn and adhere to it in life. "Kinanthi song" has a "Wewaton" rhyme: $8 \mathrm{u}$ $8 \mathrm{i}-8 \mathrm{a}-8 \mathrm{i}-8 \mathrm{a}-8 \mathrm{i}$. Kinanthi character also has the same meaning as "kanthi", "gandheng", and "kanthil" in Javanese. "Kinanthi" is likely to reveal a happy feel, love and affection, as well as role model in life. So, "Kinanthi song" is also appropriate and can be used for song lyrics that aim to convey advice and also the story of love.

Another example is "Mijil Song": 


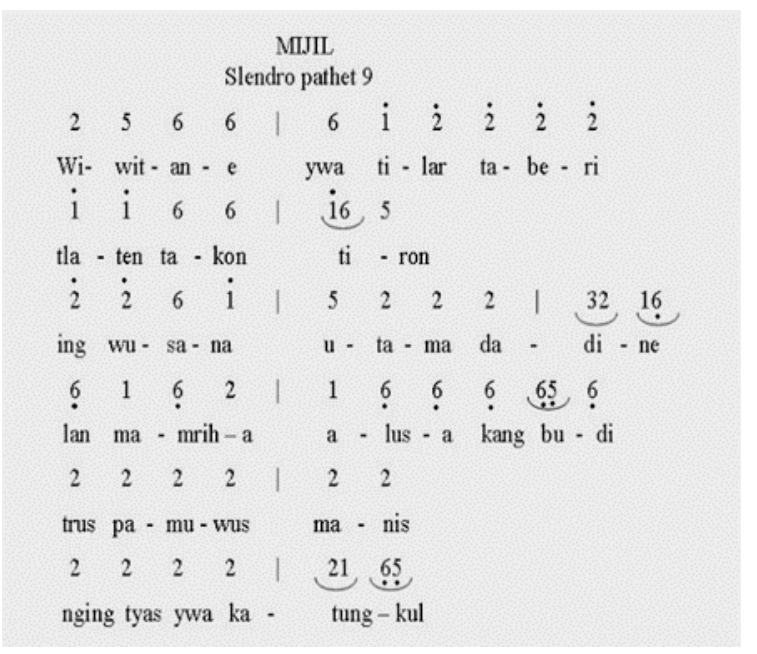

Philosophically, "Mijil song" means the beginning of child's presence in the world, which means a child is born from my mother's womb. Other words of "mijil" in Javanese are "wijil", "wiyos", "raras", "medal", "sulastri" which means out. Giving a birth is the process by which a mother is fighting life or death for herself and her child. No matter what the process, there is love and hope from the whole family. The baby "mijil" from his mother's womb is sacred; he cannot choose to be born from whom; like paper the baby is still clean as white as the snow. When the baby was born then he/she sees the world for the first time; he/she was given the authority to live in the world. He is presented to be "human" until one day he/she return to God peacefully.

The theme of the macapat song "mijil" is "compassion", "hope", "attitude" and love. Macapat "mijil" is widely used as a medium to give advice, love story, and motivation to be strong and steadfast in the world. The feeling of sadness and happiness are reflected in the "macapat mijil song". "Mijil song" which have guru gatra: 6 lines each stanza, guru wilangan: 10, 6, 10, 10, 6, 6 and guru song: i, o, e, i, i, u. "Tembang Mijil" has a "rhyme" rule: $10 \mathrm{i}$ $60-10 \mathrm{e}-10 \mathrm{i}-6 \mathrm{i}-60$.

There are some obstacles in teaching macapat song to primary school students, both from students and the teachers. Among the problems are: not all class teachers have skills teaching Java songs; the students are having difficulty in memorizing the lyrics; not all students are familiar with this Javanese song; The students are reluctant to learn as the songs are considered out of date. Some of the students join the lesson as prescribed by the school for class promotion.

\section{Geguritan}

Geguritan is a modern Javanese poetry. The geguritan taught to primary school students SD N 1 Tambahrejo and SD N 2 Sukorejo (Kendal District) are as follows:

\section{Ki Hajar Dewantara \\ By : Bisri Nuryadi}

Ing adheme hawa Walanda

Sira panggah netepi setya

Nyawiji ing ngilmu

Ngugemi ing laku

Nyerat ing saben-saben wektu

Nalika ati krasa

krungu swara jerite sedulur

Ing lemah Pertiwi

Sira gumregah greget

Bali ing desa mijilmu

Nuswantara

Suwardi Suryaningrat

Kondhang kanthi asma Ki Hajar Dewantara

Putra kraton sugih bandha brana

Milih dadi satriya lelana

Manunggal sajroning rakyat jelata

Gugur dadi pahlawan Negara

Minangka Bapak Pendhidhikan Bangsa

While for those students of SD N 2 Sekaran and SD N 2 Ngijo (Semarang City) the researchers used the following geguritan:

\section{Pamulangan \\ By: Budhi Setyawan}

Jare simbah aku kudu sekolah

Kareben dadi bocah genah mrenah ora nggladrah

Jare rama ibu aku kudu sregep mangkat Kareben dadi wong pangkat urip ora kesrakat mlarat

Jare bapak ibu guru aku kudu sinau Tambah ilmu

Kareben kelakon kabeh kang tinuju

Nanging

Prakanca, ....

Coba delengen kahanan nyata Apa isih bisa pamulangan kang ana 


\author{
dadekake urip tumata \\ Pamulangan kang tanpa tuladha \\ Pamulangan kang kasatan piwulang \\ Pamulangan kang ngajarake angka-angka \\ wuta \\ siji lan siji ana pira? \\ Jare anut kang duwe kersa \\ Jan ora weruh subasita, trapsila, apa maneh \\ tata krama \\ lali dosa... \\ Kabeh lurung binarung kumalungkung \\ Pamrih pamuji siji \\ Pamulangan ora aweh pepadang \\ Simbah, \\ Nyuwun pangapunten \\ Kula mboten kepingin dados dokter \\ Jalaran duite bapak mboten wonten sakoper \\ Rama, \\ Nyadong duka \\ Kulo mboten kapilut drajat pangkat \\ Jalaran ajrih sumpahing rakyat \\ Kang panggah mlarat sekarat \\ Bapak ibu guru, \\ Nyuwun donga pangestu \\ Mugi-mugi sedaya ilmu saged dados sangu
}

After teaching the students with Javanese song and poems, the researchers also send them to various competitions of Javanese culture. For example to the Islamic Macapat and Geguritan Competition held by UPTD Pageruyung District, UPTD Sukorejo District, and UPTD Kendal district. Students of SD N 1 Tambahrejo and students of SD N 2 Sukorejo successfully became the winner. Students of SD N 2 Sekaran and SD N 2 Ngijo also sometimes beat other participants.

After teaching those students, they are used to speaking the Javanes language either "ngoko alus" or "krama". They can write Java script, love geguritan, eager to learn macapat song, and behave more politely. It is in accordance with what has mentioned by Lickona that moral knowledge, moral feelings and moral behavior are related one to another. Moral knowledge will affect moral feelings and moral feelings will influence moral behaviour. Students who have a good knowledge of Javanese moral values will influence their moral feelings and include moral behaviour. For example, students who have knowledge of Javanese both "ngoko" and "krama" will understand the use of the two languages, when speaking to parents, they will use "krama", while talking to their peers or juniors, they will use "ngoko alus". When he/she pass in front of the parents, then he/she will say "nuwun sewu" with bowing body.

\section{CONCLUSIONS}

Teaching character education to primary school students through Javanese ethno-linguistics is very important to do because psychologically speaking by studying Javanese vernacular, Javanese script, macapat song and geguritan, students show positive changes of their characters. They show more appreciation to others; they love their indigenous heritage, have good manners, use kromo alus (the most polite style), and become more obedient to their parents. These results are so much different from their characters before the treatment.

\section{REFERENCES}

[1] Dale, Roger. 2000. Globalization and Education: Demonstrating A "Common World Educational Culture" or Locating A "Globally Structured Educcational Agenda"?. Educational Theory. Vol. 50. No. 4

[2] Rupérez, Francisco López. 2003. Globalization and Education. Prospects. Vol. XXXIII. No. 3. September 2003.

[3] Ball, Stephen J dan Anthony Gary Dworkin, Marios Vryonides. 2010. Current Sociology. Vol. 58 No. 4. July 2010. pp 23-529.

[4] Waters, 1995. Routledge: London

[5] Brown dan Lauder. 1996. Education, Globalization and Economic Development.. Journal of Education Policy. Vol. 11 No. 1. pp. $1-25$

[6] Brown. 1999. Challenging Globalization as Discourse and Phenomenon. International Journal of Lifelong Education. Vol. 18 No. 1. pp. 3-17.

[7] Cheng, 2004. Economic Considerations in Education Policy Making: A Simplified Framework. International Journal of Educational Management. Vol. 16 No. 1. pp. 18-39

[8] Syeirazi', M. Kholid. 2003. Dilema Praktis Globalisme Neoliberal. Jurnal Ham Sosial dan Ilmu Politik. Vol. 7. No. 1, Juli 2003. pp.1-34. ISSN 1410-4946

[9] Jati, Wasisto Raharjo. 2013. Memahami Globalisasi sebagai Evolusi Kapitalisme. Global \& Strategis,.Th. 7. No. 2. pp. 241-258.

[10] Sunandar. 2015. Melayu dalam Tantangan Globalisasi: Refleksi Sejarah dan Berubahnya Sistem Referensi Budaya. Jurnal Khatulistiwa Journal of Islamic Studies. Vol. 5 No. 1. Maret 2015. pp. 60-73.

[11] Susanto, Joko. 2000. Kajian Teoritik tentang Pengaruh Globalisasi terhadap Proses Demokratisasi. Masyarakat, Kebudayaan dan Politik. ThXIII. No 2. April 2000.pp 59-72. 
[12] Winanti, Poppy S. 2003. Developmental State dan Tantangan Globalisasi: Pengalaman Korea Selatan. Jurnal Ilmu Sosial dan Ilmu Politik. Volume 7. Nomor 2. Nopember 2003. pp $175-$ 204. ISSN 1410-4946.

[13] Subhilhar dan Indra Kesuma Nasution. 2006. Dunia Islam di Tengah Globalisasi. Jurnal Wawasan. Februari 2006. Vol. 11. No. 3. pp 3647.

[14] Hamzah, Fansuri. 2012. Globalisasi, Postmoderisme dan Tantangan Kekinian Sosiologi Indonesia. Jurnal Sosiologi Islam. Vol. 2. No.1. April 2012. ISSN: 2089-0192.

[15] Hrynyshyn, Derek. 2012. Technology and Globalization. Studies in Political Economy A Socialist Review. Vol. 67. No. 1. pp. 83-106.

[16] Cheng, Yin Cheong. 2000. A CMI-Striplization Paradigm for Reforming Education in The New Millennium. International Journal of Educational Management. Vol.14 No. 4. pp. 156-74.

[17] Cheng, Yin Cheong, Ng, K.H. and Mok, M.M.C. 2001. Economic Considerations in Education Policy Making: A Simplified Framework. The International Journal of Educational Management. Vol. 16 No. 1. pp. 18-39.

[18] Cheng, Yin Cheong. 2004. Fostering Local Knowledge and Human Development. The International Journal of Educational Management. Volume 18. Number 1. 2004. pp. 7-24.

[19] Lickona, Thomas. 1992. Educating for Character: How Our Schools Can Teach Respect and Responsibility. New York: Bantam Books.

[20] Hesti Astria Wijayanti, Fitro Nur Hakim. 2012. Media Pembelajaran Interaktif Akara Jawa Berbasis Flash. Jurnal Teknologi Informasi dan Komunikasi. Vol. 3 No.2 Agustus 2012. pp. 2129.

[21] Koesoema, Doni A. 2010. Pendidikan Karakter: Strategi Mendidik Anak di Zaman Global. Jakarta: Grasindo.

[22] Khan. 2010. Pendidikan Karakter Berbasis Potensi Diri: Mendongkrak Kualitas Pendidikan. Yogyakarta: Pelangi Publishing

[23] Asmani, Jamal. 2011. Buku Panduan Internalisasi Pendidikan Karakter Sekolah. Jogjakarta: Diva Press.

[24] Ganiajri, Faqihani dan Awaludin Romadhoni dan Erosa Dewi N. 2011. Permainan Hanihon Sebagai Media Pembelajaran Aksara Jawa.
Jurnal Ilmiah Mahasiswa. Vol.1 No.1. September 2011.

[25] Yani, 2012. Penggunaan Media Kartu Huruf dalam Pembelajaran Aksara Jawa di Sekolah Dasar. Kalam Cendekia PGSD Kebumen. Vol. 1. No. 2

[26] Sutarsih, 2015. Pembelajaran Menulis Aksara Jawa Anak Kelas III Sekoah Dasar. Jurnal Aksara. Vol. 27. No. 1. Juni 2015. pp 65-72. ISSN 0854-3283

[27] Zulnuraini, 2012. Pendidikan Karakter: Konsep, Implementasi Dan Pengembangannya di Sekolah Dasar di Kota Palu. Jurnal DIKDAS. No.1. Vol.1. September 2012.

[28] Suciptaningsih, Oktaviani Adhi. 2014. Peran Pendidikan Dasar dalam Penanaman Nilai-Nilai Anti Korupsi. Prosiding Seminar Nasional Upaya Pemberantasan Korupsi di Indonesia UNNES. Maret 2014. Semarang: Widya Karya

[29] Inoguchi, Takashi. 2000. "National Identity and Adapting to Integration: Nationalism and Globalization in Japan." Pp. 216-233. In: Nationalism and Globalization: East and West (edited by Leo Suryadinata) Singapore: Institute of Southeast Asian Studies.

[30] Putra, Sri Ahimza. 1997. Etnolinguistik: Beberapa Bentuk Kajian. Makalah dalam Temu Ilmiah Temu Ilmiah Bahasa dan Sastra. Yogyakarta: Balai Penelitian Bahasa

[31] Abdullah, Wakit. 2013. "Kearifal Lokal dalam Bahasa dan Budaya Jawa Masyarakat Nelayan di Pesisir Selatan Kebumen (Sebuah Kajian Etnolinguistik)". Disertasi. Surakarta: Universitas Sebelas Maret.

[32] Hidayatullah,M. Furqon. 2009. Pendidikan Karakter : Membangun Peradaban Bangsa. Surakarta : Yuma Pustaka.

[33] H.A.R Tilaar. 2002. Pendidikan, Kebudayaan, dan Masyarakat Madani Indonesia. Bandung: Remaja Rosdakarya.

[34] Koesoema A., Donie, 2007. Pendidikan Karakter. Jakarta: Grasindo.

[35] Sugiyanto, Alip. 2015. Kajian Etnolinguistik terhadap Perbahasa Etnik Jawa Panaragan sebuah Tinjauan Pragmatik Force. Prosiding Seminar Nasional Prasasti II "Kajian Pragmatik dalam Berbagai Bidang”. ISBN : 978-602-734980-3.

[36] Sartini. Ni Wayan. 2009. Menggali Nilai Kearifan Lokal Budaya Jawa Lewat Ungkapan (Bebasan, Saloka, dan Paribasa). Logat Jurnal Ilmiah Bahasa dan Satra. Vol. V. No. 1 April 2009. pp. 28-37 
[37] Hidayatullah, Arief. 2013. Nilai-Nilai Pendidikan Karakter pada Tokoh Wayang Semar. Skripsi. UIN Sunan Kalijaga Yogyakarta.

[38] Setiawati, Roswari. 2014. Pendidikan Karakter dalam Pembelajaran Bahasa Jawa pada Siswa Kelas V di MIN Yogyakarta 1. Skripsi. UIN Sunan Kalijaga Yogyakarta.

[39] Supartinah. 2010. "Peningkatan Penguasaan Aksara Jawa Pada Siswa Kelas IV SDN Golo Pendekatan Cooperative Learning Tehnik Jigsaw dan Media Kartu Aksara". Skripsi. Yogyakarta: FKIP UNY.

[40] Wardhani, Nanda Amri dan Sumarwati, Purwadi. 2016. Upaya Meningkatkan Ketrampilan Berbicara melalui Pembelajaran Berbasis Masalah pada Siswa Sekolah Dasar: Penelitian Tindakan Kelas. BASASTRA Jurnal Penelitian Bahasa, Sastra Indonesia dan Pengajarannya. Volume 4 Nomor 2, Oktober 2016, ISSN I2302-6405

[41] Utari, Nur Rita Dewi. 2013. Kemampuan Berbahasa Jawa pada Siswa Sekolah Dasar di SD N Tandes Kidul I/110 Surabaya. Skriptorium. Vol. 1, No. 3.

[42] Susanti, Liyana dan Nasirotul Awaliyah, Suhartono, Suripto. 2012. Pendekatan Integratif dan Media Kartu Huruf dalam Pembelajaran Membaca dan Menulis Aksara Jawa Siswa Kelas IV SD. Kalam Cendekia PGSD Kebumen. Vol. 1. No 1 